\title{
Effect of freezing and thawing rates on sperm motility in Bocachico Prochilodus magdalenae (Pisces, Characiformes)
}

\author{
Efecto de la congelación y descongelación sobre movilidad \\ espermática en Bocachico Prochilodus magdalenae \\ (Pisces, Characiformes)
}

\author{
José G. Martínez, ${ }^{1}$ M.Sc, Sandra Pardo $C_{1}{ }^{2 *}$ Ph.D. \\ ${ }^{1}$ Universidade Federal do Amazonas, Instituto de Ciências Biológicas, Laboratório de Evolução \\ e Genética Animal -LEGAL, Manaus, Brasil. ${ }^{2}$ Universidad Nacional de Colombia sede Medellín, \\ Facultad de Ciencias Agrarias, Departamento de Producción Animal, BIOGEM, Medellín, Colombia \\ *Corresponding: scpardoc@unal.edu.co
}

Recibido: Enero de 2011; Aceptado: Agosto de 2012.

\begin{abstract}
Objective. To determine the freezing and thawing rates necessary to maintain sperm viability during cryopreservation of Bocachico semen. Materials and methods. Four interactional treatments were implemented between two freezing (rapid and slow) and two thawing (rapid and slow) curves, in a 2×2 factorial as follows: rapid freezing-rapid thawing, rapid freezing-slow thawing, slow freezingrapid thawing, and slow freezing-slow thawing. After thawing by Sperm Class Analyzer (SCA) curvilinear velocity (VCL) and straight-line (VSL) ( $\left.\mu \mathrm{m} \mathrm{sec}^{-1}\right)$ were analyzed; total, rapid, medium, and slow motility, were compared among treatments. Results. The rapid freezing-slow thawing treatment was lethal for all variables of velocity and motility, causing a significant $(p<0.01)$ postthaw inmotility of $100 \%$. The slow freezing-rapid thawing interaction had a significantly higher effect than the other treatments $(\mathrm{p}<0.05)$, particularly on variables such as rapid motility $(10.1 \pm 1.1 \%)$, medium motility $(30.16 \pm 4.1 \%)$, and curvilinear velocity $\left(51.5 \pm 4.75 \mu \mathrm{m} \mathrm{sec} .^{-1}\right)$ also decreased the percentage of sperm with slow motility $(41.7 \pm 4.45 \%)$. Independently of the applied thawing rate, the freezing rate generated the main significant effect on total motility. Conclusions. It is possible to conclude that the interaction effect between freezing and thawing rates is nil (except for slow motility) during cryopreservation process. However, the independent effects of these factors (main effects) on remaining motility variables are positively significant and decisive to the maintenance of these features, especially the freeze factor (when it is slow). This becomes the first successful report of sperm cryopreservation from Bocachico Prochilodus magdalenae in the world and may be used in conservation programs for this endangered species.
\end{abstract}

Key words: Cryopreservation, freezing, motility, sperm, thawing (Source:CAB). 


\section{RESUMEN}

Objetivo. Determinar la tasa de congelación y descongelación para mantener la viabilidad espermática durante la crioconservación seminal de Bocachico. Materiales y métodos. Fueron implementados cuatro tratamientos de interacción entre dos curvas de congelación (rápida, lenta) y dos curvas de descongelación (rápida, lenta) en un factorial 2×2, así: congelación rápida-descongelación rápida, congelación rápida-descongelación lenta, congelación lenta-descongelación rápida y congelación lenta-descongelación lenta. Posterior a la descongelación espermática y mediante el software Sperm-Class-Analyzer, fueron analizadas la velocidad curvilínea (VCL) y lineal (VSL) ( $\mu \mathrm{m} \mathrm{sec}^{-1}$ ); movilidad total, rápida, media y lenta, y fueron comparadas entre tratamientos. Resultados. El tratamiento congelación rápida-descongelación lenta fue letal para las variables de velocidad y movilidad espermática, causando una significativa $(p<0.05)$ inmovilidad pos-descongelación $(100 \%)$. La interacción congelación lenta-descongelación rápida tuvo un efecto significativamente mejor $(\mathrm{p}<0.05)$ que los demás tratamientos, particularmente sobre variables como movilidad rápida (10.1 $\pm 1.1 \%)$, movilidad media (30.16 $\pm 4.1 \%)$ y velocidad curvilínea $\left(51.5 \pm 4.75 \mu \mathrm{m} \mathrm{sec}{ }^{-1}\right)$, así mismo, generó una disminución del porcentaje de espermatozoides con movilidad lenta $(41.7 \pm 4.45 \%)$. La tasa de congelación posee un efecto principal significativo sobre la movilidad total. Conclusiones. El efecto de la interacción entre las tasas de congelación y la descongelación es nulo (excepto para la movilidad lenta), sin embargo, los efectos independientes de estos factores (efectos principales) sobre el resto de variables de movilidad son positivamente significativos y determinantes para el mantenimiento de aquellas características, especialmente el factor congelación (cuando es lento). Este es el primer reporte exitoso de crioconservación espermática de Bocachico $P$. magdalenae en el mundo, pudiendo ser usado en programas de conservación de esta especie en riesgo de extinción.

Palabras clave: Crioconservación, congelación, espermatozoides, descongelación, movilidad (Fuente:CAB).

\section{INTRODUCTION}

The Bocachico P. magdalenae (Steindachner) is a native South American fish belonging to the Prochilodontidae Characiformes that is distributed in the Colombian rivers of Magdalena, Cesar, San Jorge, Cauca, Rancheria, and Sinu (1). Prochilodus spp. is a reopholic fish of economic importance in South America. According to the National Institute of Fishing and Aquaculture (INPA) (2), from 1986 to 1995 its capture by means of extractive fishing decreased its presence from 28501 to 5690 tons. Currently, the Bocachico is an endangered species in Colombia (3).

Due to the economic importance and environmental risk for Yamú Brycon amazonicus (Spix \& Agassiz) (4), and Cachama blanca Piaractus brachypomus (Cuvier) (5), sperm cryopreservation protocol has been standardized for each species. The development of biotechnology tools, such as sperm cryopreservation, could contribute to the development of gene banks for conservation of this species and improve the reproductive processes in aquaculture, mainly for stock enhancement programs of water bodies from the planting of fingerlings.

Cryopreservation affects sperm morphology and ultrastructure, which lead to damage of the cytosolic and nuclear membrane (6). Its effects have been also documented in genome and proteome $(7,8)$ and are shown to decrease the quality (such as motility and velocity) and viability of post-thawed spermatozoa, influencing fertilization success (9).

Most of the cellular damage occurring during cryopreservation is associated with intracellular crystallization during the reduction of temperature in freezing (10) and/or thawing of cryopreserved spermatozoa due to water bath temperature (11).

It is known that formation of ice crystals can be reduced by the addition of chemical factors such as cryoprotectants, which at no toxic concentrations to cell, can lower the internal and external freezing point diminishing the appearance of this phenomenon and increasing cell post-thawing viability. This gives importance to their presence during this process (7). In fact, dimethylsulfoxide (DMSO) is the most widely used cryoprotectant in successful spermatic post-thawing survival among South American Characiformes and other economically important fish $(12,13)$. However, ice crystal formations that cause cellular damage during 
freezing-thawing may depend upon the rate of decrease or increase of this temperature (14). Likewise, these velocities must be standardized for each species individually. South American Characiformes such as Curimba Prochilodus lineatus (Valenciennes) and Piracanjuba Brycon orbignyanus (Valenciennes), although phylogenetically close, require rapid freezing rates. However, there is only success in postthawing sperm viability if slow thawing is applied in the case of semen of $P$. lineatus (15), contrary with $B$. orbignyanus, which requires a rapid thawing rate in order to acquire the same viability $(66-82 \%$ of total motility) $(16,17)$.

Concerning these results and their variability between species, there are some hypotheses that may be presented for explanation: 1 . If freezing is sufficiently slow, the balance is achieved through efflux of water, but if freezing is very rapid, the cell can lose water fast enough to reach the equilibrium potential, which causes intracellular freezing (18-20), 2. Normally, slow freezing rates produce large crystals and injure cellular ultrastructure, however, at rapid freezing rates small intracellular ice formations occur that may become safe, but can potentially grow and unite during thawing by means of recrystallization $(11,18)$, especially if it is slow (14). This process is promoted by an inappropriate thawing velocity, which should correspond to the freezing rate used (21). Thus, for rapid freezing, rapid thawing should correspond and for slow freezing, a slow thawing likewise should correspond.

The aim of this study was to determine which of these hypotheses on freezing and thawing rates fulfills or is applicable to preserve post-thawing semen quality in $P$. magdalenae, assessed by sperm motility. This study becomes the first successful report of Bocachico P. magdalenae sperm cryopreservation in the world.

\section{MATERIALS AND METHODS}

Animals and gamets collection. Semen from three Bocachico $P$. magdalenae males $(190 \pm 10 \mathrm{~g})$ was used separately in this experiment. The semen sample taken from each male was divided into four equal parts (experimental units) and each was randomly assigned to a treatment. All specimens were part of a group of brood fish adapted and kept in captivity in ponds of the Fish Research Center (CINPIC), University of Córdoba, Colombia. The specimens were selected according to their sexual maturity (22), caught, and moved to circular enclosures of managing $\left(6 \mathrm{~m}^{3}\right)$ where they remained for 24 hours, in order to accustom them to experimental conditions, reducing the stress intensity generated by manipulation and environmental change.

Final maturation of gonads and the spermiation were obtained by an intramuscular injection of carp pituitary extract (CPE), equivalent to $4.5 \mathrm{mg} \mathrm{kg} \mathrm{mg}^{-1}$ of body weight (22). Six hours after hormonal induction, the broodfish were anaesthetized with 2-phenoxyethanol (300 ppm, Sigma Chemical Co., St. Louis, MO, USA). Semen was obtained by abdominal cephalocaudal massage, collected in one Eppendorf plastic tube of $1.5 \mathrm{~mL}$, preventing contamination (by a previous process of hand-stripping the coelomic cavity near the intestines, and drying of the urogenital papillae) with traces of water, urine, or feces. The first sperm evaluation was conducted immediately in order to know whether sperm quality was adequate for cryopreservation, taking total and rapid motility (\%) as a criterion, and having each sample ( 1 per male) respectively exceed values of $80 \%$ and $75 \%$ to be considered qualifiable.

\section{Sperm cryopreservation and freezing-} thawing rate evaluation. Diluent for $P$. magdalenae was a solution of distilled water with $12 \%$ chicken egg yolk (v/v), 6\% (333 mM) glucose $(\mathrm{w} / \mathrm{v})$ and $10 \%(1402 \mathrm{mM})$ dimethylsulfoxide (DMSO, Sigma Chemical Co., St. Louis, MO, USA) (v/v) as internal cryoprotectant.

Each of the experimental units (semen subsample) was mixed with the diluents + cryoprotectant at a rate of 1 part of semen to 3 parts diluent + cryoprotectant separately (non pooled), packaged in $0.5 \mathrm{~mL}$ straws (IMV, Instrument de Médecine Vétérinaire, Minneapolis, USA), sealed with polyvinyl (powder) and subjected any of the four different freeze-thaw treatments, generating 12 straws, 3 per treatment.

For freezing of straws, a programmable freezer (FreezeControl ${ }^{\circledR}$, CryoLogic Pty. Ltd., Victoria, $\mathrm{AU})$ was used, assisted by CryoGenesis ${ }^{\mathrm{TM}}$ software, in whose cryochambers straw groups were located to be frozen according to two different cooling rates undertaken in two steps. Thus, the rapid freezing rate consisted of a decrease of $27.3^{\circ} \mathrm{C} \mathrm{min}^{-1}\left(28^{\circ} \mathrm{C}\right.$ to $4^{\circ} \mathrm{C}$ ) and $29.9^{\circ} \mathrm{C} \mathrm{min}^{-1}\left(4^{\circ} \mathrm{C}\right.$ to $\left.-80^{\circ} \mathrm{C}\right)$, while the slow freezing rate consisted of a decrease of $2^{\circ} \mathrm{C} \mathrm{min}$ m $^{-1}\left(28^{\circ} \mathrm{C}\right.$ to $\left.4^{\circ} \mathrm{C}\right)$ and $8.2^{\circ} \mathrm{C} \mathrm{min}^{-1}$ $\left(4^{\circ} \mathrm{C}\right.$ to $\left.-80^{\circ} \mathrm{C}\right)$. Once the curve programming was complete and the temperature reached $-80^{\circ} \mathrm{C}$, the straws were immediately moved 
to a thermal storage (MVE 24/2V, TO, USA), immersed directly into liquid nitrogen $\left(-196^{\circ} \mathrm{C}\right)$ where they remained for three days. They were later extracted and thawed according to the established rates.

The thawing was performed by immersing straws in serological bath (Memmert ${ }^{\circledR}$ WNB7, $\mathrm{GmbH}$ Co. KG, Germany). Thus, a first group of straws was subjected to immersion in water bath to achieve a rapid thawing rate: $60^{\circ} \mathrm{C}$ for 8 seconds, while another group was subjected to a slow thawing rate: $30^{\circ} \mathrm{C}$ for 16 seconds. Straws were dried and semen was extracted and tested for its motile characteristics.

Both the velocity of freezing and thawing (rapid and slow) were selected according to their success in closely related species and freshwater such as Curimba Prochilodus lineatus, Yamú Brycon amazonicus, and Striped catfish Pangasius hipophtlamus (Sauvage) $(4,15,23)$, with the intention of trying to fulfill the aforementioned hypotheses (see Introduction).

Estimation of motile characteristics. To determine the effectiveness of the treatments motility was tested, considering percentage of spermatozoa with rapid (velocity $>100 \mu \mathrm{m} \mathrm{sec} .^{-1}$ ), medium ( $>40$ to $100 \mu \mathrm{m} \mathrm{sec} .^{-1}$ ), slow ( $>3$ to 40 $\left.\mu \mathrm{m} \mathrm{sec} .^{-1}\right)$, and total motility, as well as curvilinear and straight-line velocity. In all cases, to estimate motilities $0.25 \mu \mathrm{L}$ of fresh or cryopreserved semen was placed on a Makler counting chamber (Sefi, Medical Instruments Ltd., Israel). Motility for fresh semen was then activated with $75 \mu \mathrm{L}$ of distilled water to a final semen:water ratio of 1:301 and for cryopreserved semen (Already diluted with cryoprotectant + diluents) with $18.75 \mu \mathrm{L}$ of distilled water to a final ratio of $1: 76$ (standardized on the software to capture between 300 and 400 sperm per field), and the sample was analyzed through a phase contrast optical microscope (Nikkon, E50i, Japan) adapted to a seminal analysis system on a computer-assisted Sperm Class Analyzer (SCA VET 01, Microptic SL, Spain), obtaining an average data per sample, product of two field analysis recorded within 4 seconds after sperm motility activation.

Statistical analysis. Experiment was conducted according to a randomized complete block design with a $2 \times 2$ factorial arrangement for treatments (two freezing rates $x$ two thawing rates), taking males as blockade factor to reduce experimental error generated by their genetic variability.

All data are expressed as mean \pm standard deviation. Statistical analyses were carried out using SAS version 9.0 (SAS Institute Inc., Cary, NC, USA). All data of sperm motility characteristics were tested for Brown and Forsythe's Test (homogeneity of variance) and normal distribution using the KolmogorvSmirnov's Test. Data were tested for significant effects of factors by two-way ANOVA (GLM Procedure), followed by Tukey test. Differences among interaction treatments and effects of factors were tested at a probability level of 0.05 .

\section{RESULTS}

The Brown and Forsythe's Test applied to the experimental data revealed that there is homogeneity between variances $(p>0.05)$. Likewise, the Kolmogorv-Smirnov's Test showed that data obtained of the analyzed variables were normal $(p=0.1210)$. This is sufficient to show that in this particular case $n=3$ met the requirements for performing the statistical analyses within the experimental design.

Freshspermcharacteristicspriortocryopreservation were total sperm volume extracted per male of $0.45,0.5$, and $0.79 \mathrm{~mL}$ (Average: $0.58 \pm 0.18 \mathrm{~mL}$ ), and an average of $99.93 \pm 0.05 \%$ for total motility and $77.36 \pm 1.8 \%$ for rapid motility, fulfilling the criteria for cryopreservation. These and other variables such as medium motility, slow motility, curvilinear, and linear velocities were significantly higher in fresh sperm $(p<0.05)$ when compared with post-thawed sperm from interaction treatments (data not shown).

Evaluation of freezing-thawing rates. There was no interaction effect between the freezing and thawing rates $(A * B)$ on the variables of rapid, medium and total motility, curvilinear and linear velocities $(p>0.05)$, but there was for slow motility $(p<0.05)$. However, an effect of freezing rate $(A)(p<0.05)$ on total motility was found, and there was an effect of both the freezing rate $(A)$ and the thawing rate (B) independently on variables such as rapid and medium motility and curvilinear and linear velocities $(p<0.05)($ Table 1$)$.

In figure 1 (diagram of interaction $A * B$ for slow motility) highlights the fact that when thawing rate becomes slow and interacts with a rapid thawing rate, the result is the annulment of slow motility; however, the interaction with a slow freezing rate, guarantees a significant increase of the same variable. In turn, slow motility could remain practically constant at any level (rapid or slow) of freezing factor whenever thawing was rapid. 
Table 1. Analysis of the interaction and main effects of factors A (freezing rate) and B (thawing rate) on motility and spermatic velocity variables.

\begin{tabular}{lcccccc}
\hline $\begin{array}{l}\text { VARIA- } \\
\text { BLE }\end{array}$ & $\begin{array}{c}\text { A factor } \\
\text { (freezing rate) }\end{array}$ & $\begin{array}{c}\text { B factor } \\
\text { (thawing rate) }\end{array}$ & \multicolumn{2}{c}{$\begin{array}{c}\text { A*B } \\
\text { (interaction) }\end{array}$} \\
\cline { 2 - 7 } & F-Value & P-value & F-value & P-value & F-value & P-value \\
\hline $\begin{array}{l}\text { Rapid } \\
\text { motility }\end{array}$ & 8.41 & 0.0199 & 8.30 & 0.0205 & 4.32 & 0.0712 \\
$\begin{array}{l}\text { Medium } \\
\text { motility }\end{array}$ & 14.07 & 0.0056 & 9.23 & 0.0161 & 0.80 & 0.3980 \\
$\begin{array}{l}\text { Slow } \\
\text { motility }\end{array}$ & 5.72 & 0.0438 & 0.62 & 0.4536 & 6.59 & 0.0333 \\
$\begin{array}{l}\text { Total } \\
\text { motility }\end{array}$ & 10.74 & 0.0112 & 3.26 & 0.1088 & 2.35 & 0.1638 \\
$\begin{array}{l}\text { Curvilinear } \\
\text { velocity }\end{array}$ & 32.71 & 0.0004 & 11.75 & 0.0090 & 1.27 & 0.2933 \\
$\begin{array}{l}\text { Straight- } \\
\text { line } \\
\text { velocity }\end{array}$ & 18.05 & 0.0028 & 7.14 & 0.0283 & 1.67 & 0.2322 \\
\hline
\end{tabular}

Independently of the applied thawing rate, the freezing rate (A) most significantly affected total motility (Table 1 ), increasing the value of this variable especially when freezing rate was slow.

When analyzing the main effects of factor $A$ (freezing rate) in each of the levels of factor $B$ (thawing rate), it was found that whenever thawing rate becomes slow, variables such as rapid motility, medium, curvilinear velocity, and straight-line velocity also decrease, more significantly when freezing rate was rapid (Figure 2).
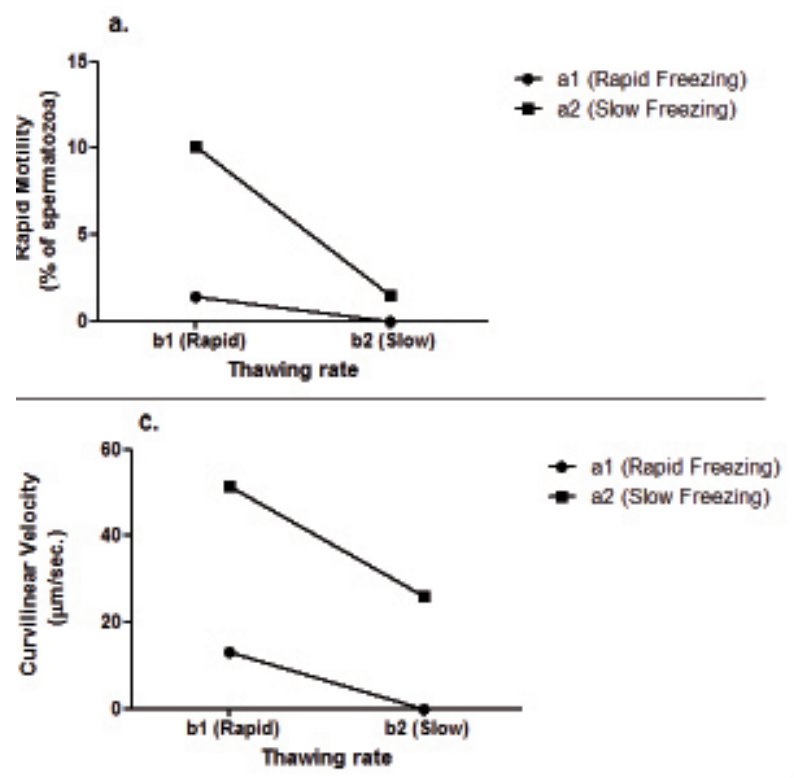

a.

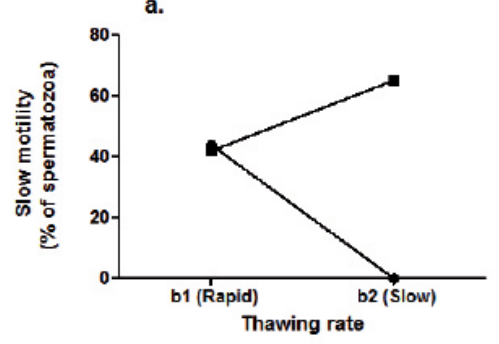

a1 (Rapid Freezing)

a2 (Slow Freezing)

b.

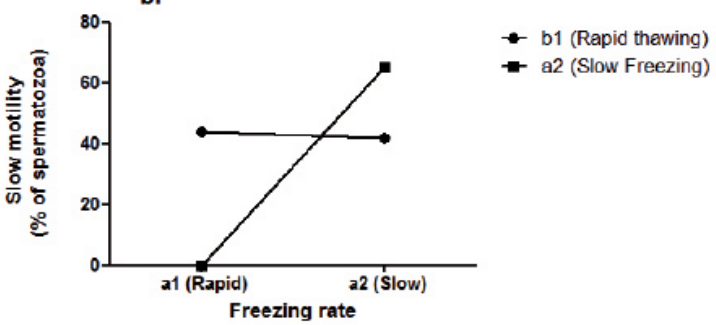

Figure 1. a. Analysis of the main effects of factor $A$ (freezing rate) in $B$ (thawing rate) and $\mathbf{b}$. factor $B$ in $A$ for variables where there was interaction $(A * B)$ : Slow motility.

Likewise, when we analyzed the main effects of factor B in each of the levels of factor A, it was found that when freezing rate becomes slow, rapid and medium motility, curvilinear velocity and straight-line velocity also increase, especially when thawing rate become fast.

Moreover, when the interaction treatments are compared each other, we found that the slow
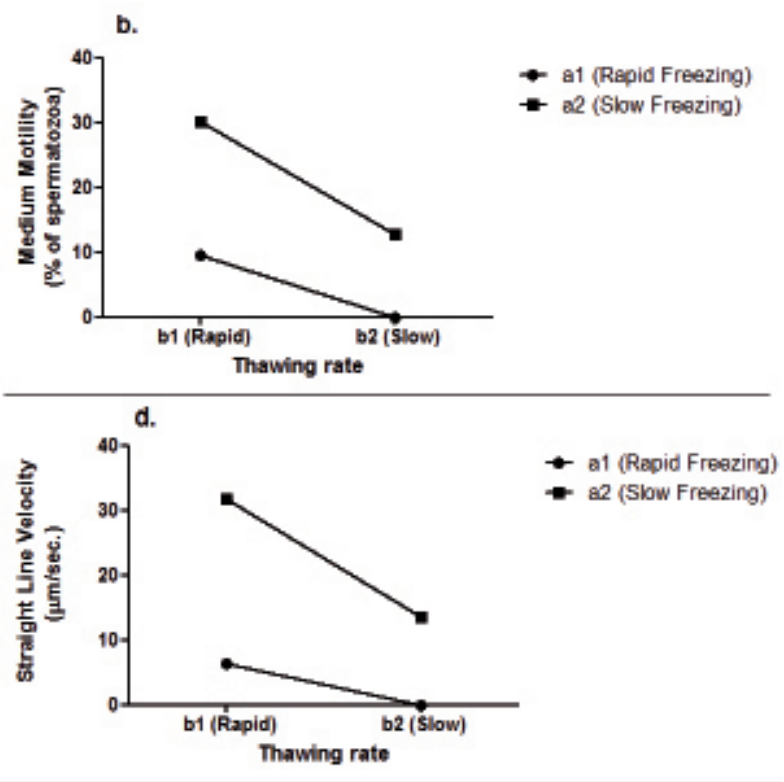

Figure 2. Analysis of the main effects of factor $A$ (freezing rate) in $B$ (thawing rate) and of $B$ in $A$ for variables where there was no interaction $(A * B)$ : a. Rapid motility, b. Medium motility, c. Curvilinear velocity, and $\mathbf{d}$. Straight-line velocity. 
freezing rate in interaction with rapid thawing rate had a significantly higher effect than the other treatments $(p<0.05)$, particularly on variables such as rapid motility $(10.1 \pm 1.1 \%)$ (Figure 3a), medium motility (30.16 $\pm 4.1 \%$ ) (Figure 3b), and curvilinear velocity (51.5 \pm $4.75 \mu \mathrm{m} \mathrm{sec} .^{-1}$ ) (Figure $3 \mathrm{c}$ ).

Regarding total motility (Figure 3d), the highest values were for treatments where freezing rate was slow $(83.63 \pm 8.75 \%$ and $79.26 \pm 6.19 \%)$. However, they did not differ statistically from total motility in treatment where freezingthawing were rapid $(54.93 \pm 5.67 \%)(p>0.05)$. Nevertheless, all have a significant difference of the treatment generated by the interaction rapid freeze-slow thaw $(0.0 \pm 0.0 \%)(p<0.05)$.
This same behavior was noted by slow motility (Figure 3e), although the lowest percentage of sperm that showed this type of motility was observed in the treatment of slow freeze-rapid thaw $(41.7 \pm 4.45 \%)$. For its part, straight-line velocity also reached its highest values in the slow freezing-rapid thawing interaction (31.76 $\pm 2.6 \mu \mathrm{m} \mathrm{sec}^{-1}$ ) being statistically different only from those treatments whose freezing rate was rapid $\left(6.33 \pm 1.21 \mu \mathrm{m} \mathrm{sec} .^{-1}\right.$ and $\left.0 \mu \mathrm{m} \mathrm{sec} .^{-1}\right)$ $(p<0.05)$ (Figure 3f).

For all motility and speed variables, the treatment of interaction between the rapid freezing rate and slow thawing rate generated values of $0.0 \pm 0.0 \%$ and $0.0 \pm 0.0 \mu \mathrm{m} \mathrm{sec}{ }^{-1}$, respectively $(p<0.05)$. a.

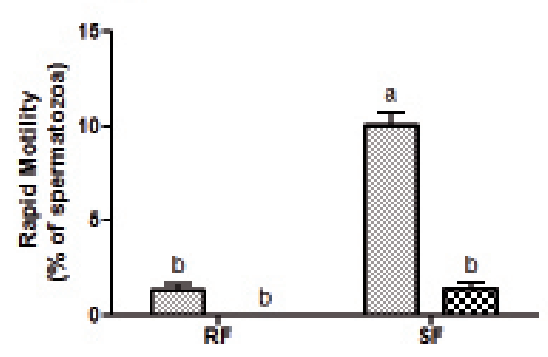

c.

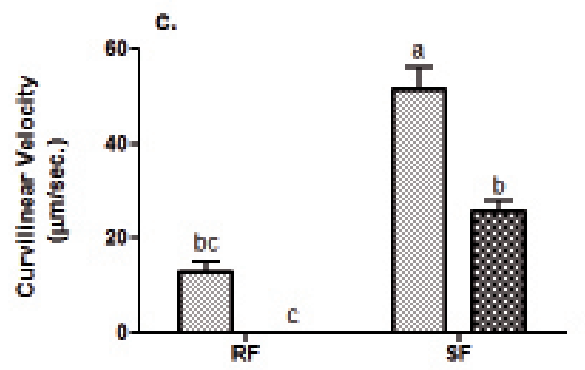

e.

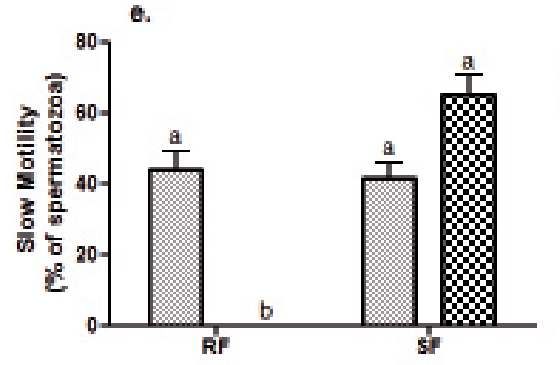

b.

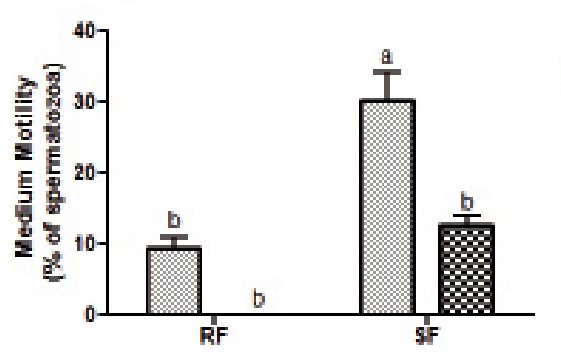

d.

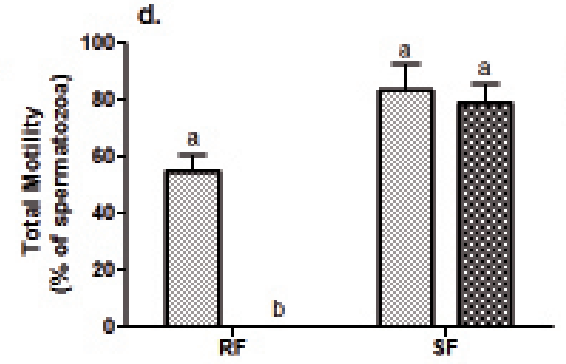

$\square$ Repid Thawing

B Slow Thewing

Slow Than Slow Thawing

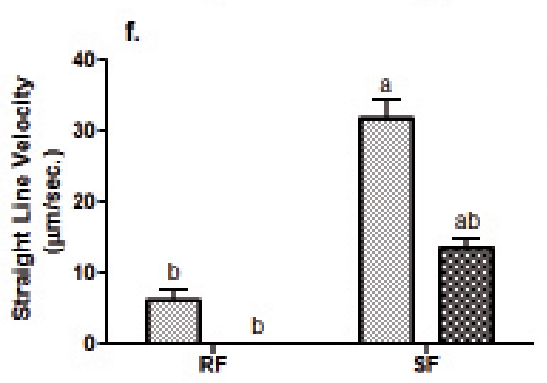

Figure 3. Multiple comparisons between treatments of interaction generated from factors of freezing and thawing rate. a. Percentage of spermatozoa with rapid motility post-thaw; b. Percentage of spermatozoa with medium motility post-thaw; c. Curvilinear velocity ( $\mu \mathrm{m} \mathrm{sec.-1)}$ of spermatozoa post-thaw; d. Total motility (\%) of spermatozoa post-thaw; e. Percentage of spermatozoa with slow motility post-thaw; $\mathbf{f}$. Straight line velocity $\left(\mu \mathrm{m} \mathrm{sec} .^{-1}\right)$ of spermatozoa post-thaw. In all cases results are (means \pm standard deviation) from 4 treatments of interaction between two freezing rates (rapid:RF and slow:SF) and two thawing rates (rapid and slow) $(\mathrm{n}=3)$. RF: rapid freezing, $27.3^{\circ} \mathrm{C} \mathrm{min} \mathrm{m}^{-1}\left(28^{\circ} \mathrm{C}\right.$ to $\left.4^{\circ} \mathrm{C}\right)$ and $29.9^{\circ} \mathrm{C}$ $\mathrm{min}^{-1}\left(4^{\circ} \mathrm{C}\right.$ to $\left.-80^{\circ} \mathrm{C}\right)$, SF: slow freezing, $2^{\circ} \mathrm{C} \mathrm{min}-1\left(28^{\circ} \mathrm{C}\right.$ to $\left.4^{\circ} \mathrm{C}\right)$ and $8.2^{\circ} \mathrm{C} \mathrm{min}^{-1}\left(4^{\circ} \mathrm{C}\right.$ to $\left.-80^{\circ} \mathrm{C}\right)$, Rapid thawing: water bath at $60^{\circ} \mathrm{C}$ during $8 \mathrm{sec}$, Slow thawing: water bath at $30^{\circ} \mathrm{C}$ during $16 \mathrm{sec}$. Bars with different letters are different $(p<0.05)$. 


\section{DISCUSSION}

The decreased motility and velocity reveal that the cryopreservation process generates damage affecting sperm cell performance, and this change results according to the interaction of freeze-thaw velocities, allowing for the inference of the importance of the two events and the need to establish the best for every particular species. This study found that semen subjected to slow freezing and rapid thawing presented higher values for all the variables of motility and velocity. On the contrary, it was found that when semen was frozen with a rapid velocity and was thawed slowly, an immobility of $100 \%$ resulted in sperm cells. This could be due to cell damage caused by the interaction of events of freezing and thawing.

Pegg (14) mentions that a rapid cooling rate restricts the necessary time to allow the cell to undergo adequate water loss during the freezing process, which facilitates the intracellular crystallization as a result of remaining excess water. This negatively affects cellular ultrastructure and viability. On the contrary, Pegg asserts that water loss is a necessary event during freezing process and is dependent on a slow cooling rate of cells, which diminishes the possibility of core formation and association, leading to the formation of ice crystals that negatively affect the cell and could make it unfeasible.

Notwithstanding, one can deduce that the best way to ensure successful survival and viability of a cell subjected to the cryopreservation process would be through the application of a slow freezing curve and a rapid thawing rate. This would generate respective form, adequate dehydration (hence no ice crystal formation), and minimizing recrystallization risks. On the contrary, it is possible to deduce that an interaction between a rapid freezing rate paired with slow thawing would generate greater damage to a cell subjected to the cryopreservation process since under both velocities.

Additionally, when the average percentage of all the variables was compared to the treatment groups, rapid freeze against slow freeze groups (regardless thawing rate), it is observed that the highest average is reached for those with slow freeze, and the lowest for those of rapid freeze. When it slow freezing velocity was implemented, independently of the thaw rate, there was always some kind of sperm survival. The same happens with other freshwater fish, such as striped catfish Pangasius hypophtalmus and African catfish Clarias gariepinus (Burchell). Cryopreserved sperm of these species, reached a peak of survival $(20,23)$ at a slow velocity (5 to $10^{\circ} \mathrm{C} \mathrm{min-1).} \mathrm{It} \mathrm{suggests} \mathrm{that} \mathrm{all} \mathrm{the}$ assumptions made by Pegg (14) apply perfectly in this experiment to $P$. magdalenae and some species, for which also the freezing rate proves to be more decisive and influential role in ensuring some kind of cell survival.

Although for Bocachico $P$. magdalenae interaction between slow freezing with rapid thawing is useful, taking into account the results in terms of rapid motility, medium motility, curvilinear velocity, and straight line velocity $(10.1 \pm 1.1 \%, 30.1 \pm 4.1 \%, 51.5 \pm 4.75 \%$ and $31.76 \pm 2.6 \%$ respectively), it is not equal for some species of freshwater as mandarin fish Siniperca chuatsi (Basilewsky), for whom a relatively rapid two-step freezing rate $\left(18^{\circ} \mathrm{C}\right.$ $\mathrm{min}^{-1}$ and $39.2^{\circ} \mathrm{C} \mathrm{min}^{-1}$ ) in combination with a slow thawing rate $\left(37^{\circ} \mathrm{C}\right.$ for 60 seconds) results in total motilities up to $91 \%$ (24). Characiforme fish response to freezing and thawing rates vary. For example, for Curimba $P$. lineatus rapid-freezing with slow-thawing as $30^{\circ} \mathrm{C}$ for 16 seconds generates total motilities up to $87 \%$ (15), while for P. magdalenae $0 \%$ motilities are reached.

For $P$. lineatus, thawing velocity is inconsecuential, regardless of rate $\left(60^{\circ} \mathrm{C}\right.$ for 8 seconds or $30^{\circ} \mathrm{C}$ for 16 seconds). Both velocities ensure total motility rates of $86.5 \%$ on average. Nevertheless, when $P$. magdalenae had rapid freezing (like $P$. lineatus) and rapid thawing $\left(60^{\circ} \mathrm{C}\right.$ for 8 seconds) there were total motilities of up to $54.93 \%$ on average, which significantly changed when a slow thawing rate was used ( $0 \%$ of total motility). Similarly, for another Characiforme such as Yamú Brycon amazonicus, a rapid freezing rate with a slow thawing rate generates higher total motilities (35.3\%) than those originated when rapid thawing rates were used (7.2\%) (25). This is evidently opposite to what results with $P$. magdalenae, where the rapid thawing always generates the greatest results.

It is necessary to study additional research in order to identify the specific mechanisms of every species that give place to such variations, which is generally attributed to intrinsic resistance of cells during this process. According to Kopeika \& Kopeika (10), it is possible that sperm cells have attributes that allow them to prevent damages and to develop cold resistance during freezing. In the case of P. lineatus, resistance to rapid freezing rates may be due to evolutionary biological adaptations to distant latitudes of 
Ecuador, which is native to southern Brazil, Uruguay, Argentina, etc., where temperatures vary significantly throughout the year. Thus, water temperatures can reach values under $15^{\circ} \mathrm{C}$ during winter, and over $30^{\circ} \mathrm{C}$ during summer (26), which shows a species flexible to changes in temperature. On the contrary, $P$. magdalenae is a tropical fish that spends its entire life in environments without significant temperature variations. Thus, in the main rivers where it lives (Sinu and Magdalena), the temperature reaches values between $28^{\circ} \mathrm{C}$ and $30^{\circ} \mathrm{C}$ maximum (27). The temperature of fish rearing is known to modulate their metabolism and also to contribute to adaptive responses to abrupt temperature changes, as well as those described in organs that perform functions vital to the survival of fish. Thus, it was determined that those answers are found mostly in lipid composition changes in the cell membrane of erythrocytes, brain, liver, or muscle (28).

It is possible that these changes in lipid composition also occur in sperm cells, giving greater resistance to those who suffer this type of adaptation. In rainbow trout, fish sperm transferred to a water temperature lower than its rearing temperature exhibited a different lipid composition of the fish acclimated to warmer waters (29). In turn, post-thaw semen quality was better in the group of fish acclimated to lower temperatures compared to those acclimated to high temperatures. The positive effect of temperature may be due to lipid changes, mainly in cholesterol content (30).

It is possible to conclude that the interaction effect between freezing and thawing rates is nil (except for slow motility) during cryopreservation process, however, the independent effects of these factors (main effects) on remain motility variables are positively significant and decisive to the maintenance of these features, especially the freeze factor (when it is slow).

\section{Acknowledgments}

This work was funded by the Research Division of the Universidad Nacional de Colombia Sede Medellín (DIME) by source project: 20101007633 and the Ministry of Agriculture and Rural Development in Colombia through the project code: MADR- 2007U7723-401.

\section{REFERENCES}

1. Mojica I. Lista preliminar de las especies de peces dulceacuícolas de Colombia. Rev Acad Col Cienc Exac Fís Nat 1999; 23:547-566.

2. INPA: Instituto Nacional de Pesca y Acuicultura. Boletín estadístico pesquero colombiano de 1995. Santa fe de Bogotá: Publicaciones INPA-MADR; 1995.

3. Mojica JI, Castellanos C, Usma S, Álvarez R. Editores. Libro rojo de peces dulceacuícolas de Colombia. La serie Libros Rojos de Especies Amenazadas de Colombia. Bogotá: Instituto de Ciencias Naturales - Universidad Nacional de Colombia, Ministerio del Medio Ambiente; 2002.

4. Cruz-Casallas PE, Medina-Robles VM, Velasco-Santamaría YM. Protocolo para la crioconservación de semen de yamú (Brycon amazonicus Spix \& Agassiz 1829). Rev Col Cienc Pec 2006; 19:146-151.

5. Navarro OJ, Velasco-Santamaría YM, Cruz-Casallas PE. Evaluación de cinco crioprotectores para la crioconservación de semen de cachama blanca (Piaractus brachypomus). Rev Col Cienc Pec 2004; 17:53-59.
6. Taddei AR, Barbato F, Abelli L, Canese S, Moretti F, Rana KJ et al. Is a cryopreservation a homogeneous process?, ultrastructure and motility of untreated, prefreezing, and posthawed spermatozoa of Diplodus puntazzo (Cetti). J Cryobiology 2001; 42:244-255.

7. Zilli L, Schivone R, Zonno V, Storelli C, Vilella $S$. Evaluation of DNA damage in Dicentrarchus labrax sperm following cryopreservation. J Cryobiology 2003; 47:227-235.

8. Zilli L, Schiavone R, Zonno V, Rossano $R$, Storelli C, Vilella S. Effect of cryopreservation on Sea Bass sperm protein. Biol Reprod 2005; 7:1262-1267.

9. Lahnsteiner $F$, Berger B, Horváth A, Urbányi B, Weismann T. Cryopreservation of spermatozoa in cyprinid fishes. Theriogenolgy 2000; 54:1477-1498.

10. Kopeika E, Kopeika J. Variability of sperm quality after cryopreservation in fish. In: Alavi SMH, Cosson JJ, Coward K, Rafiee $\mathrm{G}$ eds. Fish Spermatology. Oxford: Alpha Science Ltd. 2008. 
11. Holt WV. Basic aspects of frozen storage of semen. Anim Reprod 2000; 62:3-22.

12. Viveiros ATM, Godinhos HP. Sperm quality and cryopreservation of Brazilian freshwater fish species: a review. Fish Physiol Biochem 2009: 35:137-150.

13. Suquet M, Dreanno C, Fauvel C, Cosson J, Billard R. Cryopreservation of sperm in marine fish. Aquac Res 2000; 31:231-243.

14. Pegg D. Principles of cryopreservation. In: Day JG, Stacy GN eds. Cryopreservation and Freeze-Drying Protocols. Totowa: Human Press Inc.; 2007.

15. Viveiros ATM, Orfão LH, Maria AN, Allaman IB. A simple, inexpensive and successful freezing method for curimba Prochilodus lineatus (Characiformes) semen. Anim Reprod 2009; 112:293-300.

16. Maria AN, Viveiros ATM, Freitas RTF, Oliveira AV. Extenders and cryoprotectants for cooling and freezing of piracanjuba (Brycon orbignyanus) semen, an endangered Brazilian teleost fish. Aquaculture 2006a; 260:298-306.

17. Maria AN, Viveiros ATM, Orfão LH, Oliveira AV, Moraes GF. Effects of cooling and freezing on sperm motility of the endangered fish piracanjuba Brycon orbignyanus (Characiformes, Characidae). Anim Reprod 2006b; 3:55-60.

18. MazurP. Fundamental aspects of the freezing of cells, whit emphasis on mammalian ova and embryos. 9th International congress on animal reproduction and artificial insemination. Madrid; 1980.

19. Watson PF. The causes of reduced fertility with cryopreserved semen. Anim Reprod Sci 2000; 61:481-492.

20. Viveiros ATM, Lock EJ, Woelders H, Komen J. Influence of cooling rates and plunging temperatures in an interrupted slowfreezing procedure for semen of the African catfish, Clarias gariepinus. Cryobiology $2001 ; 43: 276-287$.

21. Mizukami A, Carrel DT, Peterson CM. Cryopreservation of embryos. In: Knobil E, Neill JD eds. Encyclopedia of Reproduction. Utah: Academic Press; 1999.
22. Atencio GVJ. Producción de alevinos de especies nativas. Rev MVZ Córdoba 2001; 6:9-14.

23. Kwantong S, Bart AN. Effect of cryoprotectants, extenders and freezing rates on the fertilization rate of frozen striped catfish, Pangasius hypophthalmus (Sauvage), sperm. Aquac Res 2003; 34:887-893.

24. Ding S, Ge J, Hao C, Zhang M, Yan W, Xu Z et al. Long-term cryopreservation of sperm from Mandarin fish Siniperca chautsi. Anim Reprod 2009; 113:229-235.

25. Medina-Robles VM, Velasco-Santamaría YM, Cruz-Casallas PE. Efecto del volumen de empaque sobre la tasa de congelación-descongelación y la fertilidad de semen crioconservado de yamú (Brycon amazonicus). Arch Med Vet 2007; 39:229-237.

26. Bennemann ST, Silva SAT, Rocha GRA. Composición ictiofaunística en cinco localidades de la cuenca del rio Tibagi, PRBrasil. Interciencia 1995; 20:7-13.

27. Tordecilla-Petro GT, Sánchez-Banda S, Olaya-Nieto C. Crecimiento y mortalidad del moncholo (Hoplias malabaricus) en la ciénaga grande de Lorica, Colombia. Rev MVZ Córdoba 2005; 10:623-632.

28. Hazel JR, Williams EE. The role of alterations in membrane lipid composition in enabling physiological adaptation of organisms to their physical environment. Prog Lipid Res $1990 ; 29: 167-227$.

29. Labbe C, Maisse G. Influence of rainbow trout thermal acclimation on sperm cryopreservation: relation to change in the lipid composition of the plasma membrane. Aquaculture 1996; 145:281-294.

30. Muller K, Muller P, Pincemy G, Kurz A, Labbe C. Characterization of sperm plasma membrane properties after cholesterol modification: consequences for cryopreservation of rainbow trout spermatozoa. Biol Reprod 2008; 78:390-399. 